\title{
ISLAMIC PROPHETIC GUIDANCE MODEL TO DEVELOP NOBLE CHARACTER IN INDONESIA
}

\author{
Hardi Santosa ${ }^{1}$, Sunaryo Kartadinata ${ }^{2}$, Juntika Nurihsan ${ }^{3}$ \\ ${ }^{1}$ Ahmad Dahlan University, Indonesia. \\ ${ }^{2,3}$ Indonesia University of Education, Indonesia. \\ email: hardi.santosa@bk.uad.ac.id \\ email: skartadinata@upi.edu \\ email: juntikanurihsan@upi.edu
}

\begin{abstract}
ABSTRACK
Oppositional behavior towards the values, norms and morals of the nation that leads to the to develop the noble character of students. The development procedure was carried out through literature study, needs assessment, content validation and empirical validation. The research method uses qualitative and quantitative approaches. The data were obtained by interviews, focus group discussions and questionnaires. Interviews involved student affairs decline of morals is a worrying phenomenon in Indonesia. For this reason, a guidance model that can improve students' noble character is needed. This study aims to produce a prophetic guidance model representatives, focus group discussions involving 7 experts in the field of guidance and counseling and questionnaires were given to 244 students. The results of the study: (1) developed prophetic guidance is based on the concept of human wholeness; (2) prophetic guidance fills in the gap of conventional guidance models which only look at human diversity as a service subject; (3) prophetic guidance has a high practical significance in answering the needs of current and future guidance and counseling services.
\end{abstract}

Keyword: guidance and counseling, Islamic prophetic, noble character

\begin{abstract}
ABSTRAK
Penelitian ini dilatarbelakangi adanya fakta empirik kebutuhan pengembangan model bimbingan untuk mengembangkan akhlak mulia mahasiswa. Sebagian mahasiswa menunjukkan perilaku oposisional terhadap nilai, norma dan moral bangsa yang mengarah pada kemerosotan akhlak. Untuk itu dibutuhkan bimbingan supaya akhlak mulia mahasiswa dapat berkembang optimal sehingga tujuan utuh pendidikan nasional tercapai. Penelitian ini bertujuan menghasilkan model bimbingan profetik untuk mengembangkan akhlak mulia mahasiswa. Prosedur pengembangan dilakukan melalui studi literatur, asesmen kebutuhan, validasi isi melalui sejumlah pakar dan validasi empirik oleh konselor perguruan tinggi. Metode penelitian menggunakan pendekatan research and development (R\&D). Hasil penelitian menunjukkan: (1) bimbingan profetik menjadi kebutuhan untuk dikembangkan; (2) pengembangan model bimbingan profetik terdiri dari model utama (primary model) dan model turunannya (secondary model); (3) bimbingan profetik yang dikembangkan telah sesuai dengan pandangan para pakar dan praktisi serta memenuhi standar kelayakan suatu model sehingga direkomendasikan untuk diimplementasikan.
\end{abstract}

Kata kunci: bimbingan dan konseling, profetik islam, akhlak mulia 


\section{A. INTRODUCTION}

Based on the Holy Qur'an Perspective, human is created in the best shape and noble (Q.S. At Tiin [95]: 4-6). The concept in this Holy Qur'an is also believed by the multicultural psychology thought that regards that human is the noble creature who want to be better and search for the life meaning by get closer to the transcendental values (Purwanto, 2007; Sutoyo, 2009). This potency is appropriate with the primary purpose of national education that intend to create the Indonesian people who believe in God, has noble character (3 section of law No. 20 year 2003 about education system). That potency seems distorted with the reality of a few young generations who show oppositional attitude toward the values, norm and nation moral that have a propensity of moral decreasing (Hasan, 2010; Zarman, 2014; Supardi, 2015).

The decreasing of noble character then followed by the consumptive life pattern, materialistic, and hedonic (Guswani \& Kawuryan, 2011; Andari, 2012; Ghani et al., 2014) that cause the humanity respect, justice, togetherness and friendship in every individual is getting ignorance more and more. If this condition is ignorance more and more, the expectation to create the noble young generation and self-admitted as Indonesian is difficult to be achieved. Related to that condition, the serious effort to guide and prepare the young generation as the primary purpose of the national education is very needed.

One of the strategic efforts to overcome the noble character problem without underestimate the other fields is education, specifically through guidance and counseling (Othman \& Suhid, 2010; binti Zakariya \& Hamid, 2012; Zarman, 2013; Kamaruddin, 2012). Various pedagogic efforts that aim to help the human development should place human integrally with the nature and God. Therefore, it can produce the spiritual-theistic paradigm as the primary fundamental in the level of education practitioner. Spiritual- theistic views human is independent to determine their attitude based on their thought, feeling and willingness, yet, in the same time time, the human also has responsibility with their natural environment, the other humans and God (Garaudy, 1982).

Nowadays, education gives the impression that ratio is put in front of, as the result rationalism appears. Meanwhile, guidance and counseling as the humanity service has not achieved yet the approach that oriented in the basic needed human as the creature whose role as the servant and leader, therefore, the intervention towards 
the human should achieve the philosophy approach which oriented to the theosentricanthropology (M. J. Yusuf, 2007).

At present, some of the people are bored and desperate in facing the life problems. for getting the calm and quietness soul and heart, the human tend to come the places that teach spiritual (Ibrahim, 2014). The research that conducted by Ibrahim (2014) has the result that support the view of the urgent need towards the education which more specific the guidance that oriented to the prophetic mission. The nation morality problem generally and the moral of the students specifically need as soon as possible response by using the intervention model that systematic, comprehensive and get in touch the human basic need that theocentric. This research considered that prophetic model guidance as the appropriate solution to overcome the nation problem generally and the students' moral problem specifically.

\section{B. LITERATURE REVIEW}

\section{Means of Action in Achieving The Perfectness of Noble Character}

In the interpretation of theological, human development tends to the effort in finding the intrinsic life value and dedicates their life to the God (Kartadinata, 2011). This Theological interpretation based on the perspective of the human essence as the servant and caliph of the God. As the creature whose dimension as the servant and caliph, human has big potential to be able do everything that pleased by the God (Nasution, 2002; Ar Raniri, 2009; Baharuddin, 2007). Seen from the purpose of creating, God tends to make the human always pray and bring the bless to universe. (QS. Ad-Dzariyat [51]: 56; Al-Anbiyâ' [21]:107). The trusteeship given by God to human as the representative of the God in the world is not the simple matter. Because in the other side, human also has the passion that potentially tends to do the bad attitude. If human is powered by the bad passion they will get in trapped to the lowest life level namely the animal level. However, if the human is able to control the passion, the will achieve the highest level of life, namely the person who has the noble character (Adz Dzakiey, 2007; Miskawaih, 1994; Nasution, 2002).

Miskawaih (1994: 14-15) asserts that the primary foundation to achieve the perfectness of noble character is clean themselves up from the bed manner before full fill it with the main character. In her analogy, Miskawaih compares with a building, it is impossible for that building in good condition, clean and health if the building is built on the mound of the rubbish, mud and feces. Miskawaih refuses 
the Greek thought that said that noble character is unchangeable because according to the Greek expert noble character is from the character and heredity. According to Maskawaih, noble character always changes based on the habitual and practice and good lesson. Yet, Maskawaih does not give the practice tips about how to achieve the perfect noble character. The teaching on noble character based on Maskawaih is related to the Islamic ethic (Kamal, 2005). So this is more philosophies. (Miskawaih, 1994) only recommends in achieving the perfectness of noble character, so the health of soul should be kept. In order to always keep the soul healthiness, the soul must do its duty to find the knowledge and practice well and seriously. Since if the soul does not think and find the life value anymore, it will be dull and brainless and lost its kindness substance. Miskawaih's idea about the perfectness of noble character named "kindness substances" directs the soul quality which always arise in the scientific knowledge. Understandable, for reaching the perfectness of noble character, someone should have knowledge that named by Maskawaih "reprehensible" and "prominent". Because reprehensible will contaminate soul and bring the human in the lowest level of life, meanwhile, the prominent is the excellent character that can bring the human in achieving the perfectness of noble character.

In the methodology-practice, (Adz Dzakiey, 2007) declares five soul sanctification and sanitation. First is increasing the spiritual quality. For increasing the spiritual quality, $\mathrm{Adz}$ Dzakiey recommends to increase the quality of worship. In this cace, the specific worship is fasting, the sunnah and obligated fasting. Second is increasing the quality of mental. The mental quality can be trained by being accustomed to positive thinking. Third is increasing the social quality. It can be done by seeing and having empathy to the other people sadness. Fourth is increasing the knowledge from all of soul of the greatest people. For increasing this knowledge, we can learn the curriculum vitae, biography and the thought of influenced and useful people. Five is asking for guidance from the expert (mursyid). Through the mursyid's guidance, someone will be more potential to do the acceleration in achieving the life goal, namely be happy here and after.

\section{Basic Concept of Prophetic}

From the etymology, the word prophetic is from English word 'prophet', that means prophet. According to oxford dictionary 'prophetic' is (1) "Of, pertaining 
or proper to a prophet or prophecy";"having the character or function of a prophet"; (2) "Characterized by, containing, or of the nature of prophecy; predictive". Therefore, prophet can be defined as the characteristic, predicative, or estimative of prophet (Ahimsa-Putra \& Budaya, 2011). From this English word that originally is from the Greek language "prophetes" namely a noun to mention the former speaker or the people who proclaimed themselves and also mean the people who speak in front of the mass (Roqib, 2011). Meanwhile, in Arabic language, prophetic means prophets that comes from the word nubuwwah. According to (Adz Dzakiey, 2007) nubuwwah or prophets has meaning all of the story that has correlation with someone whose potentially a prophet. For the meantime, (Ikmal, n.d.) interpret prophetic as the character of prophet that has characteristic as the ideal person in spiritual-individual. As the pioneer of revolution, guide the society in the right direction and keep struggling to defend the evil.

The prophetic guidance based on (Bickle, 2008) include 8 dimensions, as his statement" ...the prophetic guidance in a broader sense encompassing some eight dimensions: the revelation of God's heart, prophetic life-witnessing, scripture standard, spiritual discernment, miraculous powers, dreams and visions, social justice, and personal holiness... conclusion is that the prophetic is not just something the church does, but something it is by nature. Bickle concludes that eight issues is not only should be conducted dogmatically but also naturally as the human necessary as the creature whose part of the dimension of God.

Whereas, (Brueggemann, 2012) affirms that prophetic guidance in the context of social justice is more oriented to the effort to arise up the awareness and alternative solution of the cultural domination "... the prophetic task is to nurture, nourish, and evoke a consciousness and perception alternative to the consciousness and perception of the dominant culture around us" (A. J. Moos, 1996). Culture domination means the cultural that tends to oppress and unfair, primary in the racism, economic and political issues.

The perception of those experts above were endorsed by (Kim, 1995) who conducted the research and literature analyzes from classical until contemporary prophetic movement. Kim (1995: 23; 94) concluded that there are two primary issues in prophetic movement, namely spiritual moral and social justice. Specifically, 
spiritual moral issues tend to the supernatural power that is transcendent. This movement is oriented to the awareness that human has responsibility to the nature and God.

In contrast, social justice specifically aimed to the issues, such as: racism, economy and politic. Contemporary prophetic movement tends to arise the teosentric companionship, it is not based on social status, racism and ethnic. This movement that known as humanism, an awareness of movement that treats human based on disposition, dignity and humanity status (Shogren, 1997). Whereas the economic and political issues are oriented to rise up awareness and braveness in liberate toward the hegemony power that has a propensity to exploit the society in economic and politic to certain group (Nauss, 2013).

Specifically, Hamons (1991) defines that prophetic counseling as the assistance process through good lesson individually based on the holy book to find out the root of problem and heal the physicist. .Prophetic counseling is one-on-one ministry to help people with scriptural wisdom and insight, but also with the gifts of the Holy Spirit to discover root problems and to minister deliverance or inner healing" (Hamons, 1991 in Kim, 1995).
Seen from the prophetic task perception, area or service dimension, and general terminology stated by some experts, it can be concluded that prophetic guidance orients the giving an assistance that sourced from the Holy Qur'an and the good figure of prophet through the transcendent values, humanity and liberation aimed each individual can developed optimally as the God creature.

\section{The Frame of the Prophetic Guidance Development}

The component of prophetic guidance structurally developed based on the comprehensive component of guidance and counseling model (Depdiknas, 2007). The comprehensive guidance and counseling model proved can increase the quality of service, help the individual to live in order, assist in achieving the development optimally, also bring the characteristic individual that is better and stronger (Nurihsan, 2006). For that reasons, the outline of is need to be formulated that adapted with the guidance counseling model, such as: (1) Historical, philosophy and religious background; (2) Rational; (3) key concept; (4) Assumption; (5) goal; (6) strengthens and weaknesses; and (7) outcome. Prophetic guidance model that developed is philosophy-theoretic frame of thinking, therefore it is be directed to the practice-operational manual guidance. The 
component of prophetic guidance consist of; (1) introduction; (2) objective; (3) working step; (4) counselor qualification; (5) operational planning; (6) success indicator; and (7) evaluation and follow up.

\section{METHOD}

This research uses two approaches, namely: quantitative and qualitative. The two approaches are combined by utilizing the strengths that exist in both. It is strictly avoided the imposition of quantification on the qualitative nature and vice versa. In Creswell's terminology the merging of the two approaches is called mixed method research design and mixed method (Creswell, 2008). The development procedure was carried out through literature studies, needs assessments, content validation by a number of experts and empirical validation by college counselors. The needs assessment was carried out by giving noble character questionnaires to 244 students, interviews with four academic supervisors, representative of student affairs and community leaders in the campus environment. The data gathered was used to formulate the initial design of the model. Furthermore, content validation was carried out through four experts in the field of guidance and counseling and empirical validation through three Higher
Education counselors. Content validation was conducted by the Delphi method (Linstone \& Turoff, 2002) while empirical validation was done by focus group discussions.

\section{FINDING AND DISCUSSION}

\section{The Description Need of The Development of Prophetic Guidance}

The result of analyses on the need of model development was conducted by need analyzes of environment and counseling (Depdiknas, 2007). Refer to the result of assessment on the environment need, there is a strong indication that prophetic guidance need to be developed. The result of interview to the academic guidance lecturer, students activist and the society figure around the campus showed that the phenomenon of students' behavior tend to the moral decreasing. The next weakness is seen from the analyzing result on the student guidance program under the responsibility of the vise leader of student. That program has not full filled the appropriateness standard of the students' actual need. It can be seen from the former of participant recruitment, the students' ratio with the supervisor, strategy and guidance content.

The recruitment system is only given to the students who receive aim vision, it is obviously lose the chance for the other 
students. This system opposite to the principle guidance for all (Depdiknas, 2007). The principle of guidance for all demands all of the students have similar chance without contemplate the racism, ethnic, religion, economy level and so on. In the principal of guidance for all, guidance is given to all of the counselee, for those who have problem or not by proposing the preventive and development approach. The other weaknesses are seen from the ratio of the students with the adviser. The ratio reaches the comparison 1:70 indicates that the process of guidance is not maximal. Ideally the group guidance in large group should be consist of 12 people (Gladding, 1995; Rusmana, 2010). If the guidance is not maximal, it will implicate to the result and purposes of guidance are not optimal. It is due to the result is the impact of all of the process of guidance.

Meanwhile, in strategy perspective and guidance content, the guidance students program run is still conventional. In the advance development and guidance and counseling global issues, the guidance trends tends to achieve future education. Future education directed to have synergy both of knowledge and of technology. even, the future guidance and counseling trends direct to peace counseling, wellness, environment deficit, social justice and spiritual moral (Fakih, 2002; Rosyadi, 2004; Mastuhu, 2004; Kuntowijoyo, 2007; Roqib, 2011; Stanard et al., 2000; Miller, 2003; Cashwell \& Young, 2014; Lines, 2006; Myers et al., 2000; Witmer \& Sweeney, 1992; Nickles, 2011; Ibrahim, 2014). This implicate to the guidance strategy and content ideally take the advantages the development of advance technology also master the comprehensive content, namely include the spiritual necessary and social as the reflection of noble character (Al Syaibany, 1979; Nasution, 2002; Ar Raniri, 2009). Refer to the finding of the result assessment need, it is seemed that factually, prophetic guidance need to be developed. This conclusion based on the finding of noble character profile generally, that indicate that the students' attitude must be developed. The general description of the students' attitude described in this following figure1.

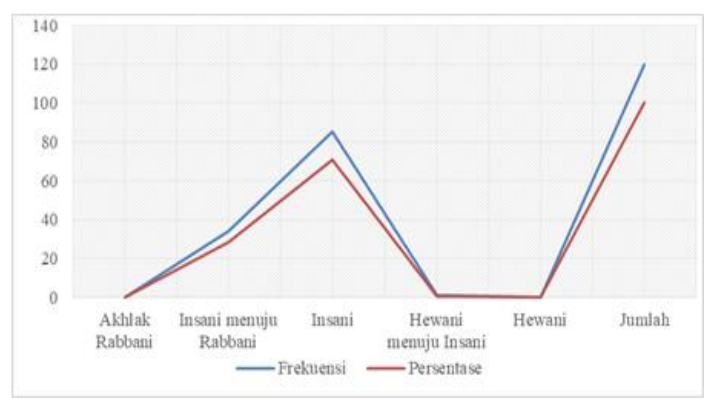

Figure1. Student Noble Character Profile

Based on the figure above, the majority $(70,8 \%)$ the student noble character is in humanity qualification that means has potential in kindness and evilness. The 
kindness potential be humanity natural tendency not automatically functioned well. In fact, sometime human is more powered by the orgasm passion and various world enjoyment therefore, the human kindeness is closed and cannot see the kindness (Tafsir, 2012; Shalahuddin, 2009). For that reason, the students need guidance in order to their good potential can be more optimal and bad potential can be minimized.

The need of guidance to keep and optimized this good potention confirmed through the result of questionnaire of the students spiritual activity. The preponderance of the student cannot comprehend their various choices, 53\% number of the students states believed in Islam because their parents are moslem, the students cannot comprehend and get the point of spiritual worship expansively, specifically praying. Although all of the respondents $(100 \%)$ state praying but in great number about $65 \%$ of the student admit that they are not full time in praying. When this analyzed further, only $7 \%$ of the students state praying in the prior time. Meanwhile, about $87 \%$ state memorize all of prayer and only $16 \%$ of the students state understand and comprehend the meaning of their prayer.

This finding indicate that kindness potential reflect to the students' noble character profile is still has potential not good. Because noble character is the fruit of believe and syariah (Marzuki, 2010). Like a building, noble character is the completeness of that building after it has strong foundation and building. Therefore, someone's noble character can be formed if they have enough faith and syari' ah (Hosen, 2005). It has been known that faith is fluctuated, as similar Islamic syari'ah which sometime on fire and in another time this is weaker, sometime it is conducted contemplate and meaningful, sometime this passes unconsciously. For strengthen the faith and spirit of worship (Miskawaih, 1994; binti Zakariya \& Hamid, 2012; AlAttas, 1980) recommended two important things, namely: knowledge and charity, knowledge be the light of heart, direction for the good and evil, and gate to achieve makrifatullah (Miskawaih, 1994). While the charity correlate to someone's spiritual experiment that give awareness and reinforcing through habits.

According to (Al-Attas, 1980) syariah experience only can be conducted more meaningful if it is supported by the sufficient knowledge. Someone who does the meaningful kindness, and consistent when they know the way also the lesson from the kindness. This sight insists that knowledge has most potential in resulting 
the permanent charity. Some mufti has achieved the consensus to more prioritize knowledge than charity, (Zarman, 2013). This also stated in Holy Qur'an as, Allah S.W.T. states

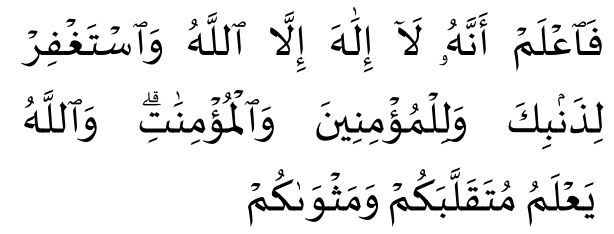

"Know, therefore, that there is no God but Allah, and ask forgiveness for your fault, and for the men and woman who believe..." (Q.S. Muhammad [47]: 19).

In that verse Allah S.W.T., commands to have knowledge first (understand) that there is not God beside Allah, then after having knowledge they should assist (beg for forgiveness). Therefore, it is clear that for getting charity or worship well, it is obligated to have knowledge on how to give charity and worship well. Even in the other verse, Allah denounces the action that conducted without the basic right knowledge.

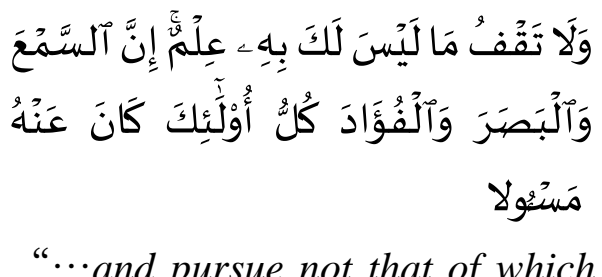
you have knowledge, for every act of hearing, or of seeing or of (feeling in) the heart will be enquired into (on the day of reckoning). (Q.S. Al-Israa'[17]: 36).
It can be firmed that noble character implemented in the form of charity action. For doing this charity action consistently, we need knowledge. If those elements are understood completely and synergic, that knowledge will bear the strong determination, raise the fire to worship, the rooted faith, strengthen the soul and humanity standard (Al Syaibany, 1979; Zarman, 2014).

Refer to the result of analyzes on environment needed and counseling, it can be concluded that there is the need of guidance model can facilitate the development of noble character. To answer that need, so, the guidance that oriented to prophetic theoretically strong predicted can overcome. The prophetic guidance based on the kindness values in holy qur'an and the prophet lesson (Kim, 1995; Bickle, 2008; J. A. Moos, 1997; Kuntowijoyo, 2007; Rosyadi, 2004; Abdullah, 2007; Adz Dzakiey, 2007; Roqib, 2011; (Ztf, 2011). Prophetic guidance orients to the achievement of the balance life here and after that reflected through three primary elements, namely: humanity, liberation, and transcendent (Kuntowijoyo, 2008; Ztf, 2011; Roqib, 2011; Kim, 1995; J. A. Moos, 1997). 


\section{The Phase of The Development Prophetic Guidance}

Procedurally, the development prophetic guidance follows the steps or phases Borg \& Gall (1983), namely the test of content validity and empiric validity. The assessment content validity process was conducted by some expert through Delphi technique while the the process of empiric test through focused discussion by involving practitioner or counselor in high education. According to (Linstone \& Turoff, 2002) there are sx general steps in implementing Delphi method, namely (1) formulate the issue (2) expose toward that issue to find the choice; (3) determine the position of prior issue; (4) identify the opinions toward that issue: (5) judge the basic reasons and (6) reevaluate choice. The issue in this research is the elements in developing prophetic development. Whereas the empiric validation through practitioner or counselors of high education conducted by using focused discussion. This described the summary of the justification result from the experts.

\section{Tabel 1.1}

The result of appropriateness through experts' examination

No

The element Appopriatene assessment ss $\begin{array}{lllll}1 & 2 & 3 & 4 & 5\end{array}$

1 The pattern of referring model

2 The foundation of developing mo Historical, philosophy, and relic

3 foundation

\begin{tabular}{clll}
4 & Rational & $\sqrt{ }$ \\
5 & Key consept & $\sqrt{ }$ \\
6 & Assumption & & $\sqrt{ }$ \\
7 & Purpose & $\sqrt{ }$ & \\
8 & Strengths and weaknesses & & $\sqrt{ }$ \\
9 & Outcame & & $\sqrt{ }$ \\
10 & Manual Guidance & & $\sqrt{ }$ \\
11 & Evaluation & & \\
\hline & Based on the analysis & result of the
\end{tabular}
content validity and empiric data as described in the table 1.1 above, it can be concluded that prophetic guidance that developed has full fill the a standard appropriateness model. Then, based on the result of conclusion in discussions with some experts, Delphi and practitioner can be quantified, that 865 prophetic guidance development has been appropriated with the experts' and practitioners' point of view. The rest about $15 \%$ is needed to be fixed. Some components that should be fixed, namely: the basic development need accommodate the idea about nuclear of human essence that is heart; and the evaluation process should add testimony from the research sample through their best experience.

The research justification result from those experts than evaluated and be the clues in perfecting the hypothetic model. First, theoretically guidance built on philosophical foundation about the human essence. The prophetic guidance model development try to find out deeply on the whole of human essence. This conceptual searching be urgent since a counselor 
should have complete thinking foundations the worldview or even personal theory in doing intervention through guidance and counseling (Kartadinata, 2011). This thinking foundation implicate to the interpretation and counseling action as the subject of guidance (Baharuddin, 2007).

Human essence in prophetic guidance perspective is regarded thoroughly as the integration of human with the nature and God (Garaudy, 1982). This perception generates spiritual-theistic paradigm as the primary foundation in guidance practical level. Spiritual-theistic paradigm regards that human is free to determine their attitude based on their thinking, feeling and willingness, but in the same time human also have responsibility toward their environment, the other human and God (Baharuddin, 2007; S. Yusuf, 2006). Therefore, all of the humans' action ideally can be responsible toward the nature, other human and the God.

Prophetic guidance believe soul element as the deepest element and the motor in all the human structure. In the human psychological structure ruhaniah aspect has spiritual and transcendental characteristic (Baharuddin, 2007; Ar Raniri, 2009). Spiritually because soul is the potential of internal supreme that came from Allah Swt, and it becomes the basic character of human. While, soul is moved by heart (Peursen, 1983). Therefore, oriented prophetic guidance development place heart as the core of human essence. Operationally, heart be the core of human as recommended by expert has been inserted in the foundation based on religious. By that addition, it means that the developed prophetic guidance has accommodated the core of human as recommended by the experts.

Second, the evaluation element of prophetic guidance be the interest some experts. As I know, that evaluation element be the barometer of the successive of guidance that oriented to prophet in developing students' noble character. In the implementation of prophetic guidance that orients in endeavouring the intelligenceheart by using individual principle, namely; by the characteristic of each individual. Hence, the successful indicator in this research should accommodate the unique spiritual experience of individual. By including, the evaluation guidance through the best testimony from the member of sample in this research, so, the element of evaluation is complete to evaluate the effectiveness of oriented prophetic guidance that developed. 


\section{E. CONCLUSION}

Referring to the purpose, finding, and the research discussion, as a result, the research questions have been answered, this research has produces the model prophetic guidance to develop the students' noble character. The guidance model produced consist of primary modal and secondary model. The primary model is theoreticphilosophy that has function as worldview or counselor personal theory, while secondary model is more practicaloperational that guide the guidance service activity, thus it is called as guidance manual.

In the guidance content perspective, the model produced consist of twelve topics, namely (10 Islamic Worldview: what and why? (2) why happy life must use knowledge (3) moral dilemma: ironic nation, (4) friendly with nature, (5) God concept: effort to strengthen the faith, (6) human concept: the effort to recognize themselves to serve the God, (7) achieve the meaningful life in order to age is not only the number, (8) globalization: croak the capitalization conspire of nation, (9) humanism in Islam: a theocentric friendship, (10) Al maun Theology: the effort to develop the social piousness, (11) ground the theology Al-maun: visiting the orphan house, (12) life only once, have achievement than pass away; build the superior and Islamic personality.

The strength of this guidance model is in the content that based on the good values in Al-Quran, the figure of prophet Muhammad Saw, all the friends, and inspirited figures. While the implementation of the strategy enforces to the powerful skills in reflective thinking in each guidance process. Therefore, it can arise the students' awareness. This model has function as facilitative service that has characteristic such as; understanding, preventive, and development.

The guidance model produced is analyzed based on the result of assessment needed. The result of assessment shows that there is the empiric needed of development prophetic guidance in developing the students; noble character. The result of questionnaire of students' noble character shows the majority $(70.8 \%)$ of the students' noble character in the humanly category. Spiritually, this finding identify there is the kindness or badness potential. For that reason, the students need guidance in order to maximize the good potential and minimize the bad potential.

To formulate this guidance model as the students' need and expectation, therefore, the procedure of development involved some experts and practitioner. The 
development of prophetic guidance model through experts and practitioner validity that inference the prophetic guidance produced has full fill the appropriateness standard model.

\section{REFERENCE}

Abdullah, A. (2007). Pengantar dalam Buku Komunikasi Profetik: Konsep dan Pendekatan. Simbiosa Rekatama Media.

Adz Dzakiey, H. B. (2007). Psikologi Kenabian: Menghidupkan Potensi dan Kepribadian Kenabian Dalam Diri. Pustaka Al Furqon.

Ahimsa-Putra, H. S., \& Budaya, A. (2011). Paradigma Profetik. Yogyakarta, makalah sarasehan Februari.

Al-Attas, M. N. (1980). The concept of education in Islam. Muslim Youth Movement of Malaysia.

Al Syaibany, O. M. (1979). Falsafah Pendidikan Islam (Langgulung Hasan, penerjemah). Bulan Bintang.

Andari, A. J. (2012). Analisis viktimisasi struktural terhadap tiga korban perdagangan perempuan dan anak perempuan. Jurnal Kriminologi Indonesia, 7(3).

Ar Raniri, S. N. D. (2009). Asrar Al Insan Fi Ma'rifah Ar-ruh wa Ar-Rahman (Rahasia Menyingkap Makrifat Allah, Alih Bahasa Agus Wahyudi). Diadit Media.

Baharuddin. (2007). Paradigma Psikologi Islami: Studi Tentang Elemen Psikologi dari al Qur'an. Pustaka Pelajar.

Bickle, M. (2008). Growing in the Prophetic. Charisma Media.

binti Zakariya, K., \& Hamid, A. (2012).
Kaedah Pembangunan Akhlak Remaja Menurut Imam al-Ghazali: Aplikasinya dalam Program Tarbiah Sekolahsekolah Menengah Aliran Agama Berasrama di Negeri Kedah, Malaysia. ATIKAN, 2(1).

Brueggemann, W. (2012). The practice of prophetic imagination: Preaching an emancipating word. Fortress Press.

Cashwell, C. S., \& Young, J. S. (2014). Integrating spirituality and religion into counseling: A guide to competent practice. John Wiley \& Sons.

Creswell, J. W. (2008). Educational Research: Planning, Conducting, and Evaluating Quantitative and Qualitative Research (3 edition). Apple Sadle River, NJ: Pearson Merril Prentice Hall.

Depdiknas. (2007). Rambu-rambu Penyelenggaraan Bimbingan dan Konseling dalam Jalur Pendidikan Formal. PMPTK.

Fakih, M. (2002). Jalan Lain: Manifesto Intelektual Organik. Pustaka Pelajar bekerjasama dengan INSIST.

Garaudy, R. (1982). Promesses De l'islam (Alih Bahasa, Rasjidi). Bulan Bintang.

Ghani, S. A., Abdullah, S., Akil, S. M. S., \& Nordin, N. (2014). Muslim adolescents moral value and coping strategy among Muslim female adolescent involved in premarital sex. Procedia-Social and Behavioral Sciences, 114: 427-433.

Gladding, S. T. (1995). Group Work: A Counseling Specialty ((2ed)). Prentice Hall.

Guswani, A. M., \& Kawuryan, F. (2011). Perilaku agresi pada mahasiswa ditinjau dari kematangan emosi. Jurnal Psikologi UMK: PITUTUR, 1(2): 8692.

Hasan, dkk. (2010). Pengembangan 
Pendidikan Budaya dan Karakter Bangsa. In Bahan Pelatihan. Puskur Kemendiknas.

Hosen, N. (2005). Religion and the Indonesian constitution: a recent debate. Journal of Southeast Asian Studies, 419-440.

Ibrahim, A. (2014). The need of discoursing social theology in Muslim Southeast Asia. Indonesian Journal of Islam and Muslim Societies, 4(1): 1-23.

Ikmal, M. (n.d.). Integrasi Pendidikan Profetik (Mengurai Tradisi dan Implemintasi dalam Sistem Pendidikan Indonesia). Dalam Jurnal Pelopor Pendidikan, 4.

Kamal, Z. (2005). Islam, negara \& civil society: gerakan dan pemikiran Islam kontemporer. Paramadina.

Kamaruddin, S. A. (2012). Character education and students social behavior. Journal of Education and Learning, 6(4): 0.

Kartadinata, S. (2011). Menguak Tabir Bimbingan dan Konseling Sebagai Upaya Pedagogis. UPI Press.

Kim, D. J. (1995). A review of literature in the contemporary prophetic movement. Fuller Theological Seminary.

Kuntowijoyo. (2007). Islam Sebagai Ilmu: Epistemologi, metodologi dan Etika. Tiara Wacana.

Kuntowijoyo. (2008). Paradigma Islam: Intepretasi Untuk Aksi. Mizan.

Lines, D. (2006). Spirituality in counselling and psychotherapy. Sage.

Linstone, H., \& Turoff, M. (2002). The Delphi method: Techniques and applications. Addison-Wesley.

Marzuki, M. (2010). Pembentukan Kultur Akhlak Mulia di Kalangan Mahasiswa Uny melalui Pembelajaran Pai. Jurnal Cakrawala Pendidikan, 1(1).
Mastuhu. (2004). Menata Ulang Pemikiran Sistem Pendidikan Abad 21. Kerjasama antara Safaria Isania Press dengan MSI UII.

Miller, G. (2003). Incorporating spirituality in counseling and psychotherapy: Theory and technique. John Wiley \& Sons.

Miskawaih, I. (1994). Мепијu Kesempurnaan Akhlak. Buku Dasar Pertama Tentang Filsafat Akhlak. Mizan.

Moos, A. J. (1996). Defining the Prophetic: Areformed and Hermeneutical Model. Princeton Theological Seminary.

Moos, J. A. (1997). Defining the prophetic: A Reformed and hermeneutical model.

Myers, J. E., Sweeney, T. J., \& Witmer, J. M. (2000). The wheel of wellness counseling for wellness: A holistic model for treatment planning. Journal of Counseling \& Development, 78(3): 251-266.

Nasution, M. Y. (2002). Manusia Menurut Al Ghazali. Raja Grafindo Persada.

Nauss, A. (2013). Implications of Brain Research for the Church: What It Means for Theology and Ministry. Lutheran University Press.

Nickles, T. (2011). The role of religion and spirituality in counseling.

Nurihsan, A. J. (2006). Akhlak Mulia dalam Perspektif Bimbingan dan Konseling Islami. Bandung: Rizki Press.

Othman, M. K., \& Suhid, A. (2010). Peranan Sekolah dan Guru dalam Pembangunan Nilai Pelajar Menerusi Penerapan Nilai Murni: Satu Sorotan. MALIM: Jurnal Pengajian Umum Asia Tenggara, 11, 117-130.

Peursen, V. C. A. (1983). Tubuh, Jiwa dan Ruh (sebuah pengantar dalam filsafat manusia). Alih bahasa oleh: K.Bertens. 
Gunung Mulia.

Purwanto, Y. (2007). Epistemologi Psikologi Islami: Dialektika Pendahuluan Psikologi Barat dan Psikologi Islam. Refika Aditama.

Roqib, M. (2011). Prophetic Education: Kontekstualisasi Filsafat dan Budaya Profetik Dalam Pendidikan. STAIN PRESS.

Rosyadi, K. (2004). Pendidikan Profetik. Pustaka Pelajar.

Rusmana, N. (2010). Group Excercise Sebagai Sarana Efektif Pendidikan Nilai dan Pengembangan Karakter. Seminar Internasional Kerjasama UPI Dan UPSI.

Shalahuddin, H. (2009). Konsep Teologi Islam: Mengkaji Klaim Rasionalisme Mu'tazilah. UIKA Press.

Shogren, G. S. (1997). Christian Prophecy and Canon in the Second Century: A Response to BB Warfield. JOURNALEVANGELICAL THEOLOGICAL SOCIETY, 40, 609-626.

Stanard, R. P., Sandhu, D. S., \& Painter, L. C. (2000). Assessment of spirituality in counseling. Journal of Counseling \& Development, 78(2), 204-210.

Supardi, U. S. (2015). Arah pendidikan di Indonesia dalam tataran kebijakan dan implementasi. Formatif: Jurnal Ilmiah
Pendidikan MIPA, 2(2).

Sutoyo, A. (2009). Bimbingan dan Konseling Islami. Teori dan Praktik. Widya Karya.

Tafsir, A. (2012). Berjalan Menuju Tuhan, Rukun Islam Sebagai Tarekat. Simbiosa Rekatama Media.

Witmer, J. M., \& Sweeney, T. J. (1992). A holistic model for wellness and prevention over the life span. Journal of Counseling \& Development, 71(2): 140-148.

Yusuf, M. J. (2007). Model Konseptual Konseling Islami dan Implikasinya Bagi Pengembangan Dakwah: Studi Perspektif Konseling Berdasarkan Hakikat Manusia Menurut Ajaran Islam. Universitas Pendidikan Indonesia.

Yusuf, S. (2006). Konseling Spiritual Teistik. Rizqi Press.

Zarman, W. (2013). Inilah! Wasiat Nabi Bagi Para Penuntut Ilmu. Ruang Kata.

Zarman, W. (2014). Konsep dan penerapan model pendidikan karakter mahasiswa unikom. Majalah Ilmiah UNIKOM.

Ztf, P. B. (2011). Prophetic social sciences: toward an Islamic-based transformative social sciences. Indonesian Journal of Islam and Muslim Societies, 1(1): 95-121. 